\title{
The Canada-US Border: Approaches to Managing Irregular Crossings
}

\author{
Alexa Kirkey*, Carleton University
}

\begin{abstract}
The Canada-US border has seen a significant spike in irregular crossings from the US into Canada since 2016. As tens of thousands of migrants have crossed into Canada outside official entry points, Canadian officials have had to grapple with how to manage these irregular asylum claims that have put enormous strain on the Canadian immigration system. In response, the Canadian government has developed an approach that sees officials conduct comprehensive security screenings to process these claims. However, the existence of the Safe Third Country Agreement (STCA) between Canada and the US has also created a challenge in dealing with this issue. In response, three approaches have emerged. The first involves completely eliminating the STCA. The second would see serious restriction of asylum claims and patrolling of borders, while the third would seek to maintain the status quo. However, the ideal solution is likely one that finds a middle ground, expediting the processing while also closing loopholes in the agreement.
\end{abstract}

Keywords: Borders, Irregular migration, Asylum seekers, United States, Safe Third Country Agreement

\section{Résumé}

Depuis 2016, il y a eu une augmentation importante de passages irréguliers des États-Unis vers le Canada à la frontière canado-américaine. Comme des dizaines de milliers de migrants sont entrés au Canada en dehors des points d'entrée officiels, les autorités canadiennes ont dû se pencher sur la gestion de ces demandes d'asile irrégulières qui ont mis à rude épreuve le système d'immigration canadien. En réponse, le gouvernement canadien a mis au point une approche qui prévoit que les fonctionnaires procèdent à des contrôles de sécurité complets pour traiter ces demandes. Cependant, l'existence de l'Entente entre le Canada et les États-Unis sur les tiers pays sûrs a compliqué la gestion de ce problème. En réponse, trois approches ont vu le jour. La première implique l'élimination complète de l'Entente entre le Canada et les États-Unis. La deuxième consiste à restreindre considérablement les demandes d'asile et les patrouilles aux frontières, tandis que la troisième cherche à maintenir le statu quo. Toutefois, la solution idéale est probablement celle qui trouve un juste milieu, en accélérant le traitement des demandes tout en comblant les lacunes de l'entente.

Mots-clés : Frontières, Immigration irrégulière, Demandeurs d'asile, États-Unis, Accord sur les pays tiers sûrs

\footnotetext{
${ }^{*}$ Biography :

Alexa Kirkey is a Second year Master of Arts candidate at Carleton University (NPSIA), with a specialization in Intelligence and International Affairs. She also holds an undergraduate degree in political science from the University of Ottawa. During her undergrad, she conducted extensive research on the Syrian refugee crisis. Her current research areas of interest include terrorism, radicalization, and migration. Alexa has also worked for multiple federal government departments through various internship and co-op programs. She completed the Winter 2020 term on exchange at the International University of Japan, in the city of Minamiuonuma.

Biographie :

Alexa Kirkey est étudiante de deuxième année à la maîtrise de la Norman Paterson School of International Affairs (NPSIA) de l'Université Carleton avec une spécialisation en intelligence et affaires internationales. Elle détient également un baccalauréat en sciences politiques de l'Université d'Ottawa. Pendant ces études de premier cycle, elle a mené des recherches approfondies sur la crise des réfugiés syriens. Ses domaines de recherche actuels incluent le terrorisme, la radicalisation et les migrations. Alexa a également travaillé pour plusieurs ministères fédéraux dans le cadre de divers programmes de stages. Elle a complété son trimestre d'hiver 2020 en échange à l'Université internationale du Japon, dans la ville de Minamiuonuma.
} 


\section{Issue Summary}

Canada and the United States have proudly touted that the border between the two countries is the longest non-militarized border in the world. The close relationship between both countries has allowed for extensive movement of both goods and people across the border for decades. However, the Canada/US border has faced challenges in recent years, particularly pertaining to irregular migration from the United States to Canada. For the purpose of this brief, irregular border crossers are those who seek to cross from the United States into Canada at a location that is not a legal port of entry. Between February 2017 and December 2019, there were 54,736 refugee protection claims made by irregular border crossers (IRB, 2020, Table 1). Of these cases, 12,255 have been accepted, but there remains close to 30,000 cases still pending (lbid). This large influx of irregular border crossers has put immense pressure on both the refugee processing system and on border towns where these irregular migrants cross. Moving forward, Canada should build on the status quo, aiming to reduce the number of asylum seekers who cross outside official entry points, while protecting the human rights of those who do.

This debate has been revived by the COVID-19 outbreak, as Canada and the United States have agreed to close their border to non-essential travel during this crisis. In March 2020, the Liberal government announced it would return irregular border crossers to the US temporarily as part of its response to COVID-19 (Austen, 2020, para. 1). Though they have remained adamant this measure is only temporary, many human rights groups are concerned this measure will remain in place longterm. However, this policy brief will examine Canada's policy towards irregular border crossers prior to the COVID-19 crisis, as well as existing policy options, and will conclude with policy recommendations based on these available options.

\section{Current policy}

To deal with the influx of irregular border crossers, the Government of Canada developed the Asylum Seeker Influx - National Strategic Response Plan (AS NSRP), which identifies three key activities to manage the situation. First, irregular border crossers are intercepted by Royal Canadian Mounted Police (RCMP), who are tasked with determining any criminal history, and assessing the individual situation to determine if the individual must remain in RCMP custody, can be transferred to a local police jurisdiction, or to the Canada Border Services Agency (CBSA) (IRCC, 2020, para. 11). The second step in the process is screening by the CBSA. Here, the CBSA will determine the individual's admissibility to Canada based on extensive background checks and interviews (Ibid, para. 13). Finally, those who make a claim for asylum must be assessed for eligibility. Both the CBSA and Immigration, Refugees and Citizenship Canada (IRCC) participate in this process, and the Government of Canada has deployed mobile teams to areas where high numbers of irregular border crossers have appeared in an attempt to reduce wait times (Ibid, para. 14). The current government considers its policy towards irregular border crossers as one that treats migrants with compassion and maintains their legal rights (Ibid, para. 1). However, this policy has been highly criticized, both for being too open and not open enough. The Canadian government has argued the existing policy is sufficient to deal with the influx of irregular border crossers as there is no evidence that these individuals have relied on smugglers to get across (Keung, 2019, para. 2). The situation thus differs greatly to irregular border crossings observed in Europe, where migrants from various countries in Africa and the Middle East rely on smugglers to make the perilous journey to Europe. The close relationship between Canada and the US is thus an important consideration in determining the best policy for the Canadian context.

\section{Policy Options}

The main driver for the influx in recent years is the hostile American approach to refugee policy (Keung, 2019, para. 9). This has also led the Safe Third Country Agreement (STCA) to be put into question. Left-leaning critics have argued the agreement, which stipulates migrants must make their asylum claim in the first safe country in which they arrive, should be suspended due to restrictive American policies (Mohammed, 2019, para. 2). By not crossing at official ports of entry, asylum seekers have identified a loophole in the STCA and can claim asylum in Canada. Because of this, 
right-leaning critics have supported rejections for all asylum seekers who do not cross at official ports of entry in order to close this loophole (Keung, 2019, para. 23). The plausible policy options in the Canadian context are cancelling the STCA to allow further asylum claims, adding additional restrictions to limit asylum claims, and maintaining the status quo.

1. Ending STCA with the US: Various NGOs such as Amnesty International have called on Canada to cancel the STCA. They argue that the existence of this agreement forces desperate individuals to brave the dangerous winter conditions by crossing into Canada between official border posts (Mohammed, 2019, para. 2). Not only do asylum claims have to be made in the US, but individuals crossing at official border points who are rejected are then returned to the US (Ibid, para. 3). It is this fear of being sent back to the US that makes people cross between official border points and as such, proponents of this approach suggest that ending the STCA would reduce the amount of people attempting to cross between official entry points. The NDP supported this notion and campaigned on the promise of the cancellation of the STCA in the October 2019 election (Harris, 2019, para. 16). From a human rights perspective, many groups have argued the agreement should be dissolved completely as the US is no longer a safe country for refugees, and legal challenges have been taken on to fight the agreement (CCR, n.d., para. 3). However, the need for Canada to maintain a close relationship with the US makes ending the agreement a complicated task with significant political costs.

2. Restricting asylum claims: During the 2019 election, Conservatives campaigned on the promise to end irregular border crossings by allowing asylum claims to be submitted only at official ports of entry, thus updating the STCA and removing the loophole (Harris, 2019, para. 1). The Liberal campaign opposed this in preference of maintaining the status quo, arguing that it would require too many resources to patrol the entire border for irregular border crossers (Ibid, para. 9). Other asylum claimants have also argued for more restrictions, stating that this loophole is unfair to those who have applied through official channels (Ibid, para. 30). The narrative promoted by the Conservatives thus suggests that the current policy leaves options for asylum seekers to make their way to Canada illegally.

3. Maintaining the status quo: Maintaining the current policy on irregular border crossers means continuing the current three step process put in place for asylum claimants who cross outside official ports of entry. To improve the current system, it will be necessary for the process to be expedited and the wait times to be shortened as the government must absorb the costs of holding asylum claimants at government facilities (Harris, 2019, para. 27). This status quo is portrayed as a middle ground between the other two potential approaches.

\section{Policy Recommendations}

According to the United Nations High Commissioner for Refugees (UNHCR), it is not illegal for those seeking asylum to cross into Canada at unofficial points of entry, as those fleeing violence or persecution are often not able to obtain the required authorization to cross (UNHCR, 2019, para. 2). Therefore, in order to respect international law, Canada's approach to irregular border crossers must allow individuals to make asylum claims even if they do not cross at an official entry point, and their claims should be processed in the same manner as those that do. So, the approach that calls for restricting asylum claims would be contradictory to international law and risks damaging Canada's reputation as a leader in immigration matters within the international community. Furthermore, this is not a viable option domestically, as it would require deploying a large amount of resources to patrolling the land border. Instead, these resources would be better used if invested in accelerating wait times for processing claims, in order to minimize the amount of time asylum claimants must be held in government facilities. This would be done by increasing the federal government's capacity to process claims. In regard to the STCA agreement, the political implications of damaging the Canada-US relationship by cancelling the agreement is the most important drawback to this approach, as it would require Canada declaring the US an unsafe country for refugees. Rather than cancelling the agreement, Canada should consider making amendments to the agreement, which would be viewed more favourably by the US than an outright cancellation. Such amendments could come in the form of temporary exemptions, broadening the category of asylum claimants exempt from the restrictions 
imposed by the agreement. Canada's approach to irregular border crossers must develop on the status quo, with focus on reducing the backlog and closing loopholes in the STCA, to reduce the number of illegal border crossers.

\section{References}

Austen, lan. (2020). In Shift, Trudeau Says Canada Will Return Asylum Seekers to U.S. (New York Times). Retrieved from https://www.nytimes.com/2020/03/20/world/canada/trudeau-asylumseekers-coronavirus.html

Canadian Council for Refugees (CCR). (n.d.). Safe Third Country. Retrieved from https://ccrweb.ca/en/safe-third-country

Harris, Kathleen. (2019). Scheer Vows to Stop Illegal Border Crossings, Prioritize Economic Immigration (CBC). Retrieved from https://www.cbc.ca/news/politics/scheer-roxham-roadasylum-seekers-immigration-1.5314527

Immigration and Refugee Board of Canada (IRB). (2020). Refugee Protection Claims Made by Irregular Border Crossers. Retrieved from https://irb-cisr.gc.ca/en/statistics/Pages/irregularborder-crossers-countries.aspx

Immigration, Refugees and Citizenship Canada (IRCC). (2020). Irregular Border Crossings - What is Canada Doing? Retrieved from https://www.canada.ca/en/immigration-refugeescitizenship/news/2018/07/irregular-border-crossings--what-is-canada-doing.html

Keung, Nicholas. (2019). Hostile U.S. Refugee Policies Stoking Irregular Migration to Canada, Study Says (The Toronto Star). Retrieved from https://www.thestar.com/news/gta/2019/10/25/hostile-us-refugee-policies-stoking-irregularmigration-to-canada-study-says.html

Mohammed, Justin. (2019). Call on Canada to End the Safe Third Country Agreement (Amnesty International). Retrieved from https://www.amnesty.ca/blog/call-canada-end-safe-thirdcountry-agreement

UNHCR. (2019). What to Know About Irregular Border Crossings. Retrieved from https://www.unhcr.ca/wp-content/uploads/2019/02/Facts-About-Irregular-Border-CrossingsFeb2019.pdf 